\title{
APLIKASI MONITORING DAN SCREENING COVID-19 MENGGUNAKAN METODE CERTAINTY FACTOR DAN FORWARD CHAINING
}

\author{
Nur Aprilia ${ }^{1}$, Fauziah $^{2}$, Ratih Titi Komala Sari ${ }^{3}$ \\ Program Studi Sistem Informasi, Universitas Nasional \\ nuraprilia99@gmail.com, fauziah@civitas.unas.ac.id, ratih.titi@civitas.unas.ac.id \\ Submitted December 2, 2020; Revised February 28, 2021; Accepted March 15, 2021
}

\begin{abstract}
Abstrak
Coronavirus disease 2019 atau COVID-19 yang disebabkan oleh SARS CoV 2 adalah sebuah tragedi dalam dunia kesehatan secara global. Bahkan Organisasi Kesehatan Dunia (WHO) telah menyatakan bahwa wabah corona virus merupakan Public Health Emergency of International Concern (PHEIC) atau darurat kesehatan masyarakat Internasional. Tidak hanya berdampak pada kesehatan tetapi wabah virus ini juga memiliki dampak yang besar diberbagai sektor seperti terganggunya perekonomian Negara, terhambatnya proses belajar mengajar dan lain sebagainya. Dampak ini disebabkan oleh penyebaran virus yang begitu cepat. Oleh karena itu, penulis merancang sebuah aplikasi monitoring dan screening COVID-19 menggunakan metode certainty factor dan forward chaining yang bertujuan untuk memudahkan masyarakat memantau penyebaran virus COVID-19 secara realtime dan dapat melakukan screening dini COVID-19. Kedua metode ini menghasilkan diagnosis sistem dengan hasil yang sama yaitu seseorang terindikasi sebagai SUSPECT COVID-19.
\end{abstract}

Kata Kunci: COVID-19, Certainty, Forward, Monitoring, Screening.

\begin{abstract}
Coronavirus disease 2019 or COVID-19 caused by SARS CoV 2 is a tragedy in the world of global health. Even the World Health Organization (WHO) has stated that the corona virus outbreak is a Public Health Emergency of International Concern (PHEIC) or an international public health emergency. Not only has an impact on health but this virus outbreak also has a major impact in various sectors such as disruption of the country's economy, obstruction of the teaching and learning process and so on. This impact is caused by the rapid spread of the virus. Therefore, the authors designed a monitoring and screening application for COVID-19 using certainty factor and forward chaining methods which aim to make it easier for people to monitor the spread of the COVID-19 virus in real time and be able to carry out early screening for COVID-19. Both of these methods produce a system diagnosis with the same results, that is, someone is indicated as SUSPECT COVID-19.
\end{abstract}

Key Words: COVID-19, Certainty, Forward, Monitoring, Screening.

\section{PENDAHULUAN}

Sejak 2019 hingga saat ini sedang terjadi wabah virus di seluruh dunia. Virus tersebut bernama Coronavirus disease 2019 atau COVID-19 yang disebabkan oleh SARS CoV 2 dan pertama kali ditemukan di Wuhan Cina [1]. Virus ini dapat menyebabkan infeksi pernapasan ringan hingga infeksi pernapasan berat. Infeksi tersebut dapat terjadi melalui droplet atau percikan air liur dari satu orang ke orang lain saat batuk atau bersin [2]. World Health Organization (WHO) sudah mengumumkan bahwa virus ini dapat menular antar manusia (human to human transmission) dan menjadi wabah di seluruh dunia [1].

Sejak kemunculannya pertama kali di Indonesia hingga saat ini, kasus COVID-19 terus meningkat jumlahnya disetiap waktu. Dengan kondisi tersebut, diperlukannya suatu aplikasi sistem pakar yang dapat 
melakukan screening mandiri gejala virus COVID-19 secara online sekaligus menyediakan fitur monitoring perkembangan dan penyebaran kasus COVID-19 di Indonesia yang dapat diakses dan digunakan oleh masyarakat secara real time. Sistem ini berbasis website menggunakan dua metode yaitu certainty factor dan forward chaining.

Mengacu pada jurnal pertama yang membahas tentang mendiagnosa penyakit osteoporosis pada lansia menggunakan metode forward chaining memperoleh hasil yang sama antara diagnosa pakar dengan diagnosa sistem sesuai rule yang diberikan oleh pakar. Sehingga sistem pakar ini dapat dikatakan berfungsi dengan cukup baik (akurat) untuk membantu mendiagnosa penyakit osteoporosis yang diderita oleh pasien [3].

Mengacu pada penelitian selanjutnya yang membahas tentang penyakit mata katarak dengan menggunakan metode certainty factor memiliki hasil akhir dengan nilai ke akurasian sebesar 95\% sehingga dapat disimpulkan tingkat keyakinan adalah hampir pasti [4].

Berdasarkan dari jurnal penelitian sebelumnya, terdapat beberapa kekurangan dimana sistem pakar tersebut hanya menggunakan satu metode diantaranya forward chaining atau certainty factor. Maka dari itu penulis mengkombinasikan metode certainty factor dengan teknik forward chaining sebagai hasil perbandingan keakuratan dalam membangun sistem pakar screening COVID-19.

Tujuan dari penelitian ini adalah agar user dapat melakukan screening dini gejala COVID-19 secara online dengan tingkat keakuratan yang tinggi. Selain itu dapat memudahkan user dalam memonitoring perkembangan kasus COVID-19 secara realtime.

\section{METODE PENELITIAN}

Pada penelitian ini penulis memaparkan metode yang digunakan untuk screening COVID-19 yaitu dengan metode certainty factor dan forward cahining, metode pengumpulan data, analisa kebutuhan sistem, sistem arsitektur monitoring dan use case diagram.

\section{Metode Certainty Factor (CF)}

Metode Certainty Factor pertama kali diperkenalkan dalam pembuatan MYCIN oleh Shortliffe Buchanan. Certainty Factor bertujuan untuk menunjukan besar kepercayaan berdasarkan nilai parameter klinis yang diberikan MYCIN [5]. Rumus dasar certainty factor diformulasikan berdasarkan konsep keyakinan dan ketidakyakinan sebagai berikut :

$$
\mathrm{CF}[\mathrm{h}, \mathrm{e}]=\mathrm{MB}[\mathrm{h}, \mathrm{e}]-\mathrm{MD}[\mathrm{h}, \mathrm{e}] \ldots \text { (1) }
$$

Keterangan :

$\mathbf{C F}[\mathbf{h}, \mathbf{e}]=$ Faktor kepastian

$\mathbf{M B}[\mathbf{h}, \mathbf{e}]=$ Measure of belief, tingkat keyakinan atau kepercayaan terhadap hipotesis (h), jika diberikan evidence (e) antara 0 dan 1

$\mathbf{M D}[\mathbf{h}, \mathbf{e}]=$ Measure of disbelief, tingkat keyakinan atau ukuran ketidakpercayaan terhadap hipotesis (h), jika diberikan evidence (e) antara 0 dan 1.

Kombinasi certainty factor terhadap premis tertentu:

1. Certainty factor dengan satu premis.

$\mathrm{CF}[\mathrm{h}, \mathrm{e}]=\mathrm{CF}[\mathbf{e}]^{* \mathrm{CF}}[$ rule $]=\mathrm{CF}[\mathbf{u s e r}] *$ CF[pakar] ...(2)

1) Certainty factor dengan kesimpulan yang serupa.

CF gabungan $[\mathrm{CF} 1, \mathrm{CF} 2]=\mathrm{CF} 1+\mathrm{CF} 2 *$ $(1-$ CF1) ...(3) 
Metode certainty factor ini memiliki keunggulan yaitu dapat digunakan pada sistem pakar dalam mendiagnosis penyakit untuk mengukur kepastian atau ketidak pastian. Perhitungan dari metode ini hanya berlaku untuk sekali hitung, serta hanya dapat mengolah dua data sehingga keakuratannya terjaga.

\section{Metode Forward Chaining (FC)}

Forward Chaining merupakan teknik yang bekerja dalam pencarian fakta yang sebelumnya telah diketahui, selanjutnya fakta-fakta tersebut dicocokan dengan bagian IF dari rules IF -THEN. Apabila ada fakta yang sesuai dengan bagian IF, kemudian rule tersebut dieksekusi. Setelah rule dieksekusi, maka sebuah fakta baru (bagian THEN) ditambahkan ke dalam basis data atau database [5].

\section{Metode Pengumpulan Data}

Metode pengumpulan data yang digunakan penulis dalam penilitian ini sebagai berikut:

1. Studi pustaka yaitu pengumpulan data yang diperoleh dari berbagai literatur seperti e-book dan jurnal penilitian yang sesuai dengan masalah yang diambil.

2. Wawancara, yaitu dengan melakukan tanya jawab bersama pakar yaitu seorang dokter umum bernama Dr. Ratih Elsa Putri S.Ked lulusan dari Fakultas Kedokteran Universitas Andalas Padang.

\section{Analisa Kebutuhan Sistem}

Kebutuhan sistem yang dibutuhkan dalam membuat apliaksi ini yaitu :

1. Perangkat Keras (Hardware)

Perangkat keras pada penilitian ini terdiri dari Laptop ASUS VivoBook X407UAR dengan spesifikasi sebagai berikut :
a. CPU Intel Core $i 37^{\text {th }}$ Gen
b. RAM 4GB
c. HDD 1 TB

2. Perangkat Lunak (Software)

Perangkat keras pada penelitian ini terdiri dari :
a. Windows 1064 bit (OS)
b. Sublime Text 3
c. Xampp

\section{Sistem Arsitektur Monitoring}

Sistem monitoring ini merupakan data statistik populasi COVID-19 di dunia maupun di Indonesia yang tidak berkolerasi terhadap metode certainty factor maupun forward chaining. Pengambilan data dan integrasi COVID-19 diambil dari 2 sumber application programming interface (API) yang berbeda, masing-masing layanan tersebut dapat dilihat dari tabel 1.

Tabel 1 Mapping API COVID-19

\begin{tabular}{ccc}
\hline Layanan & Path & Integrasi \\
\hline $\begin{array}{c}\text { Javieravi } \\
\text { les }\end{array}$ & $\begin{array}{c}\text { https://coronavirus-19- } \\
\text { api.herokuapp.com/all }\end{array}$ & $\begin{array}{c}\text { Rekap Data } \\
\text { Global }\end{array}$ \\
& & \\
Kawal & https://api.kawalcorona.com/ & Sebaran Data \\
Corona & indonesia/provinsi/ & Wilayah Lokal \\
& & Indonesia \\
& & \\
& & \\
\hline
\end{tabular}

Tabel diatas adalah sumber data kasus COVID-19 dimulai dari layanan pertama berasal dari Javieraviles yaitu sebuah akun github yang menyediakan rekap data kasus COVID-19 secara global atau seluruh dunia. Sedangkan layanan kedua berasal dari kawal korona merupakan rekap data kasus COVID-19 di setiap provinsi Indonesia. Aplikasi monitoring ini berformat JSON (JavaScript Object Notation) yang berfungsi untuk melakukan pertukaran dan penyimpanan data yang bersumber dari beberapa application programming interface (API) kemudian di visualisasikan secara real time [6]. 


\section{Use Case Diagram}

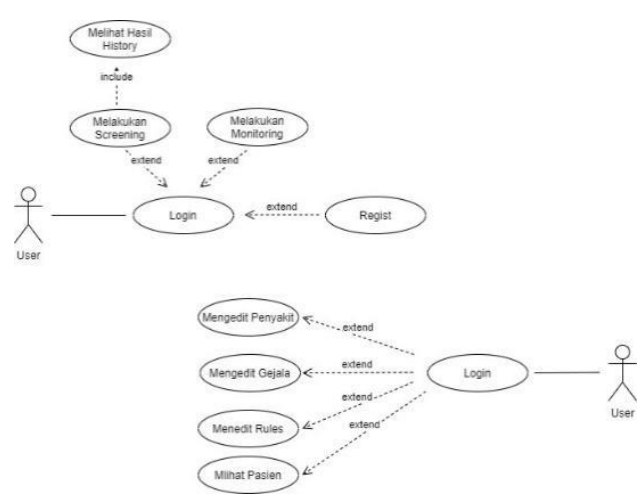

Gambar 1. Usecase Diagram Aplikasi Screening dan Monitoring COVID-19

Diagram ini menggambarkan perilaku sistem yang akan dibuat terdapat dua aktor yang terdiri dari user dan admin. Admin sendiri memiliki hak akses penuh terhadap halaman sistem sedangkan user hanya memiliki hak akses pada halaman screening, monitoring dan hasil history.

\section{HASIL DAN PEMBAHASAN}

\section{Basis Pengetahuan}

Basis pengetahuan ini didapat dari fakta dan pengetahuan dari hasil wawancara dengan seorang pakar yang nantinya digunakan sebagai basis pengetahuan untuk menentukan hipotesa atau kesimpulan dari setiap gejala yang dipilih.

\section{Tabel 2. Nilai CF User}

\begin{tabular}{lll}
\hline \multicolumn{1}{c}{ No. } & \multicolumn{1}{c}{ Jawaban User } & \multicolumn{1}{c}{ Nilai CF } \\
\hline 1. & Tidak & 0 \\
2. & Mungkin & 0,4 \\
3. & Kemungkinan Besar & 0,6 \\
4. & Hampir Pasti & 0,8 \\
5. & Pasti & 1 \\
\hline
\end{tabular}

Tabel 3. Hasil Status Pasien Ditentukan Pakar

\begin{tabular}{lll}
\hline No & \multicolumn{1}{c}{ Kode Hasil Status } & \multicolumn{1}{c}{ Hasil Status } \\
\hline 1. & KS & Suspect \\
2. & KNS & Non Suspect \\
\hline
\end{tabular}

Tabel 4. Gejala dan Nilai Bobot yang Ditentukan Pakar

\begin{tabular}{|c|c|c|c|}
\hline No & $\begin{array}{l}\text { Kode } \\
\text { Gejala }\end{array}$ & Nama Gejala & $\begin{array}{l}\text { Nilai } \\
\text { CF } \\
\text { Pakar }\end{array}$ \\
\hline 1. & G1 & Demam >38 Derajat Celcius & 1 \\
\hline 2. & $\mathrm{G} 2$ & Batuk Kering & 1 \\
\hline 3. & G3 & Nyeri Tenggorokan & 0,8 \\
\hline 4. & G4 & Bersin-bersin & 0,6 \\
\hline 5. & G5 & Sesak Napas & 1 \\
\hline 6. & G6 & Sakit Kepala & 0,6 \\
\hline 7. & G7 & Mual/Muntah & 0,6 \\
\hline 8. & G8 & Tubuh Menggigil & 0,4 \\
\hline 9. & G9 & Kebingungan Pada Manula & 0,4 \\
\hline 10. & G10 & Diare & 0,4 \\
\hline 11. & G11 & Kongesti (Hidung Tersumbat) & 0,6 \\
\hline 12. & G12 & $\begin{array}{l}\text { Anosmia (Hilangnya } \\
\text { kemampuan penciuman) }\end{array}$ & 0,8 \\
\hline 13. & G13 & $\begin{array}{l}\text { Anoreksia (Hilangnya Nafsu } \\
\text { Makan) }\end{array}$ & 0,6 \\
\hline 14. & G14 & $\begin{array}{l}\text { Fatigue (Kelelahan atau } \\
\text { lemas) }\end{array}$ & 0,9 \\
\hline 15. & G15 & Myalgia (Nyeri Otot & 0,6 \\
\hline 16. & G16 & Penurunan Keasadaran & 0,4 \\
\hline 17. & G17 & $\begin{array}{l}\text { Ageusia (Hilangnya Indra } \\
\text { Perasa) }\end{array}$ & 0,6 \\
\hline 18. & G18 & $\begin{array}{l}\text { Konjungtivitas (Mata } \\
\text { Memerah) }\end{array}$ & 0.4 \\
\hline 19. & G19 & $\begin{array}{l}\text { Pada } 14 \text { hari terakhir sebelum } \\
\text { timbul gejala memiliki riwayat } \\
\text { tinggal atau bekerja atau } \\
\text { mengunjungi keramaian atau } \\
\text { bepergian di suatu tempat } \\
\text { yang berisiko tinggi } \\
\text { penulalaran. }\end{array}$ & 1 \\
\hline 20. & G20 & $\begin{array}{l}\text { Kontak langsung atau } \\
\text { berdekatan dengan kasus } \\
\text { probable atau kasus } \\
\text { konfirmasi dalam radius } 1 \\
\text { meter dan dalam jangka waktu } \\
15 \text { menit atau lebih }\end{array}$ & 1 \\
\hline
\end{tabular}


Tabel 5. Rule atau Aturan Forward Chaining yang Ditentukan Pakar

\begin{tabular}{|c|c|c|}
\hline No. & Rule (Aturan) & Hasil Status \\
\hline 1. & $\begin{array}{l}\text { G1, G2, G7, G10, G13, G14, } \\
\text { G19 }\end{array}$ & KS (Suspect) \\
\hline 2. & $\begin{array}{l}\text { G1, G2, G3, G5, G14, G19, } \\
\text { G20 }\end{array}$ & KS (Suspect) \\
\hline 3. & $\begin{array}{l}\text { G1, G2, G3, G12, G13, G14, } \\
\text { G15, G19 }\end{array}$ & KS (Suspect) \\
\hline 4. & $\begin{array}{l}\text { G1, G2, G3, G6, G11, G12, } \\
\text { G19 }\end{array}$ & KS (Suspect) \\
\hline 5. & $\begin{array}{l}\text { G1, G2, G3, G6, G12, G14, } \\
\text { G15, G19 }\end{array}$ & KS (Suspect) \\
\hline 6. & G1, G7, G8, G10, G13, G14 & $\begin{array}{l}\text { KNS } \\
\text { Suspect) }\end{array}$ \\
\hline 7. & G7, G10, G13, G14, G15 & $\begin{array}{l}\text { KNS } \\
\text { Suspect) }\end{array}$ \\
\hline 8. & $\mathrm{G} 1, \mathrm{G} 2, \mathrm{G} 4, \mathrm{G} 6, \mathrm{G} 11, \mathrm{G} 15$ & $\begin{array}{l}\text { KNS } \\
\text { Suspect) }\end{array}$ \\
\hline
\end{tabular}

\section{Pohon Keputusan Berdasarkan Rule Forward Chaining}

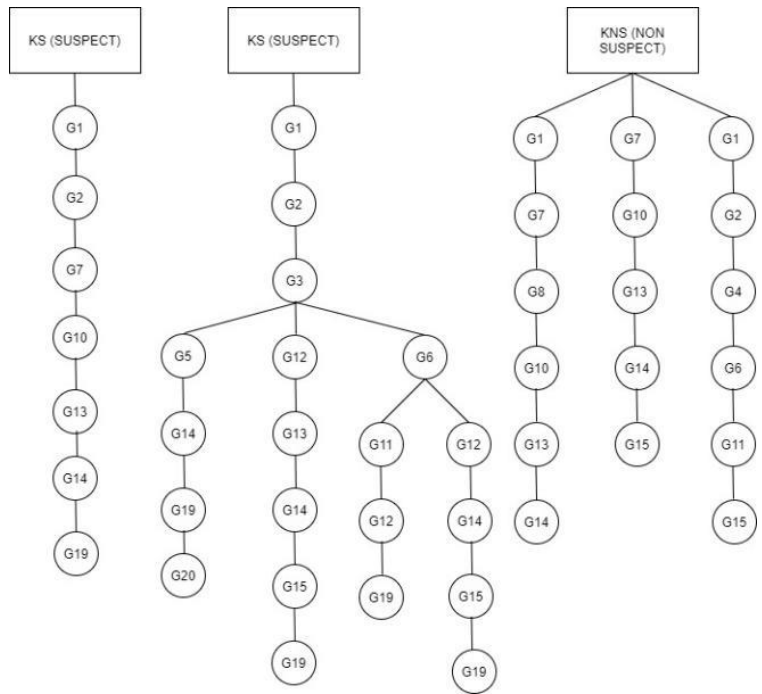

Gambar 2. Pohon Keputusan Berdasarkan Rule yang Ditentukan Pakar

\section{Pengujian Metode Certainty Factor}

Untuk melakukan pengujian pada sistem, user memilih delapan gejala untuk dijadikan sampel sebagai berikut :
1) Demam (G1)

2) Batuk Kering (G2)

3) Nyeri Tenggorokan (G3)

4) Anosmia (G12)

5) Anoreksia (G13)

6) Fatigue (G14)

7) Myalgia (G15)

8) 14 hari terakhir berpergian (G19)

Perhitungan sistem ini dilakukan secara manual menggunakan rumus persamaan 1 .

Tabel 6. Perhitungan CF Pakar*CF User

\begin{tabular}{lllll}
\hline No. & $\begin{array}{l}\text { Kode } \\
\text { Gejala }\end{array}$ & $\begin{array}{l}\text { CF } \\
\text { Pakar }\end{array}$ & $\begin{array}{l}\text { CF } \\
\text { User }\end{array}$ & Hasil \\
\hline 1. & G1 & 1 & 0.8 & 0.8 \\
2. & G2 & 1 & 0.4 & 0.4 \\
3. & G3 & 0.8 & 0.4 & 0.32 \\
4. & G12 & 0.8 & 0.4 & 0.32 \\
5. & G13 & 0.6 & 0.6 & 0.36 \\
6. & G14 & 0.9 & 0.6 & 0.54 \\
7. & G15 & 0.6 & 0.8 & 0.48 \\
8. & G19 & 1 & 0.8 & 0.8 \\
\hline
\end{tabular}

Kemudian dilanjutkan dengan perhitungan kombinasi menggunakan persamaan 3 .

Tabel 7. Perhitungan CF Kombinasi

\begin{tabular}{|c|c|}
\hline CF Kombinasi & Proses Perhitungan \\
\hline $\mathrm{CF} 1, \mathrm{CF} 2$ & $\begin{array}{l}=0.8+0.4(1-0.8) \\
=0.064 \mathrm{CF} \text { old }\end{array}$ \\
\hline CF old, CF3 & $\begin{array}{l}=0.064+0.32(1-0.064) \\
=0.36352 \mathrm{CF} \text { old }\end{array}$ \\
\hline CF old, CF4 & $\begin{array}{l}=0.36352+0.33(1-0.36352) \\
=0.43504 \mathrm{CF} \text { old }\end{array}$ \\
\hline CF old, CF 5 & $\begin{array}{l}=0.43504+0.36(1-0.43504) \\
=0.63842 \mathrm{CF} \text { old }\end{array}$ \\
\hline CF old, CF6 & $\begin{array}{l}=0.63842+0.54(1-0.63842) \\
=0.83367 \mathrm{CF} \text { old }\end{array}$ \\
\hline CF old, CF7 & $\begin{array}{l}=0.83367+0.48(1-0.83367) \\
=0.91350 \mathrm{CF} \text { old }\end{array}$ \\
\hline CF old, CF8 & $\begin{array}{l}=0.91350+0.8(1-0.91350) \\
=0,9827\end{array}$ \\
\hline Hasil Akhir & $\begin{array}{l}=\text { CF Combine } \times 100 \% \\
=0.98 \times 100 \% \\
=98 \%\end{array}$ \\
\hline
\end{tabular}


Dari diagnosis yang dipilih user berdasarkan penghitungan secara manual seperti pada tabel diatas, menunjukan hasil yang sesuai dengan diagnosis pakar pada sistem screening yang didapatkan bahwa seseorang tersebut terdiagnosis sebagai kasus suspect COVID-19 dengan tingkat presentase keyakinan mencapai $98 \%$.

\section{Pengujian Metode Forward Chaining}

Pada pengujian forward chaining masih menggunakan sample yang sama seperti certainty factor. Setelah ditelaah terhadap seluruh rule yang dipilih user menunjukan hasil diagnosis sistem bahwa user termasuk kasus suspect COVID-19. Karena dari semua rule yang dipilih user, rule ke tiga pada tabel maupun pohon keptusan yang telah terpenuhi semua rule nya.

\section{Interface Sistem}

1. Halaman Login

Sebelum dapat melakukan screening dan monitoring user terlebih dahulu harus melakukan proses login.

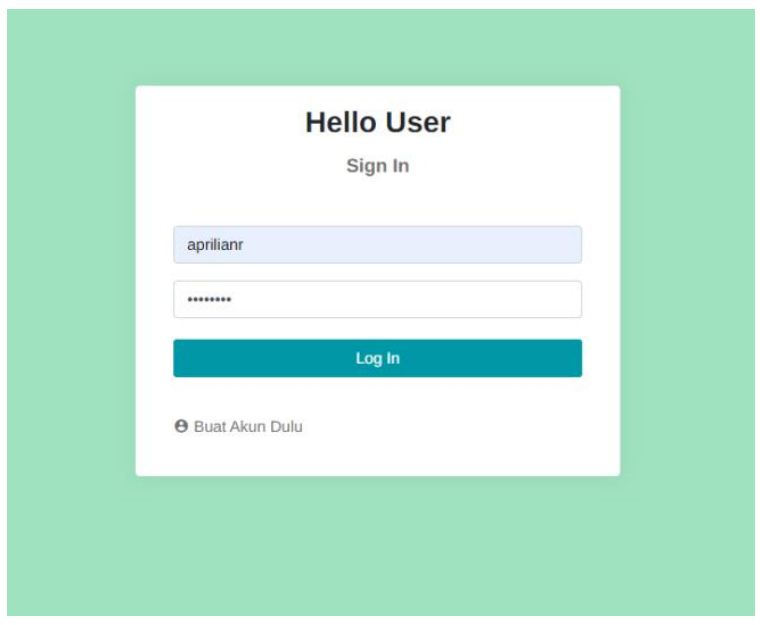

\section{Gambar 3. Halaman Login}

2. Halaman Dashboard

Halaman dashboard berisi beberapa menu yang dapat diakses oleh user.

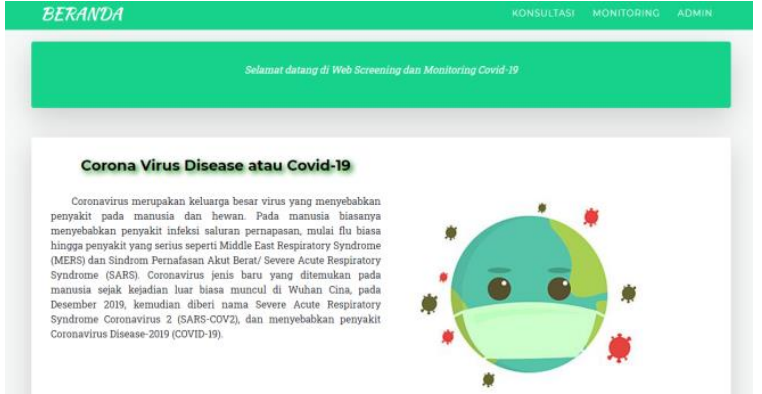

Gambar 4. Halaman Dashboard

3. Halaman Diagnosa Certainty Factor Halaman dibawah ini menampilkan daftar indikator gejala yang dapat dipilih oleh user.

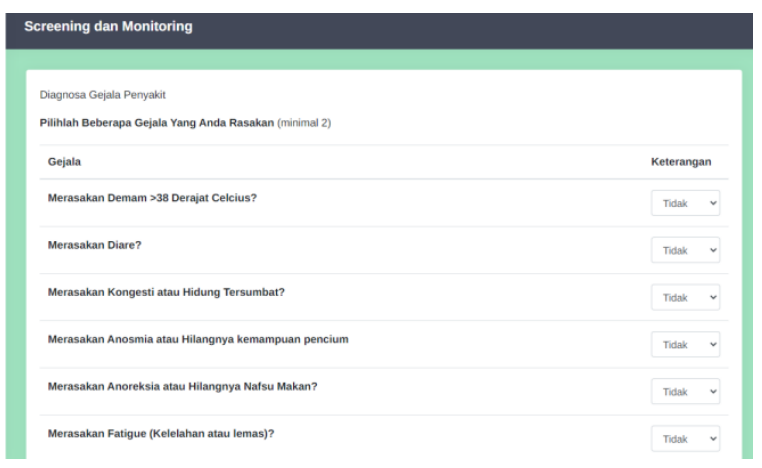

Gambar 5. Diagnosa Certainty Factor

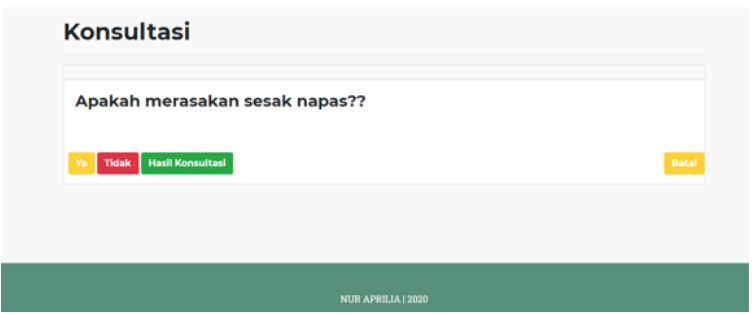

Gambar 6. Diagnosa Forward Chaining

4. Hasil Screening atau Diagnosa Halaman ini menampilkan hasil screening gejala yang telah dipilih user dari dua metode yaitu certainty factor dan forward chaining. 


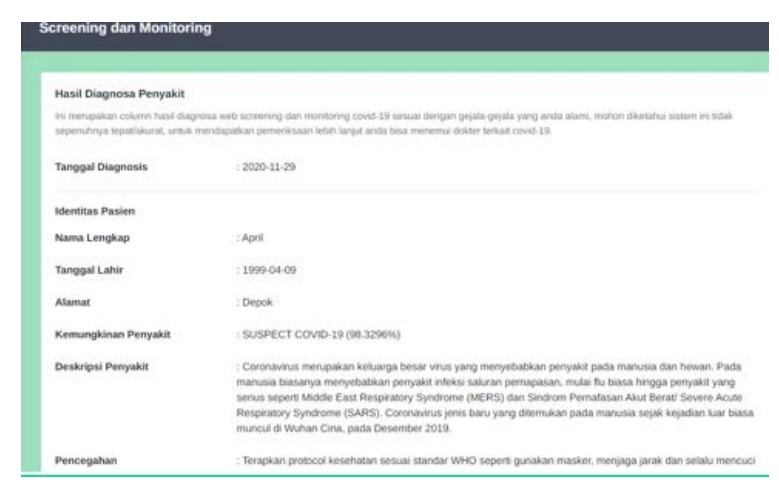

Gambar 7. Hasil Screening Certainty Factor
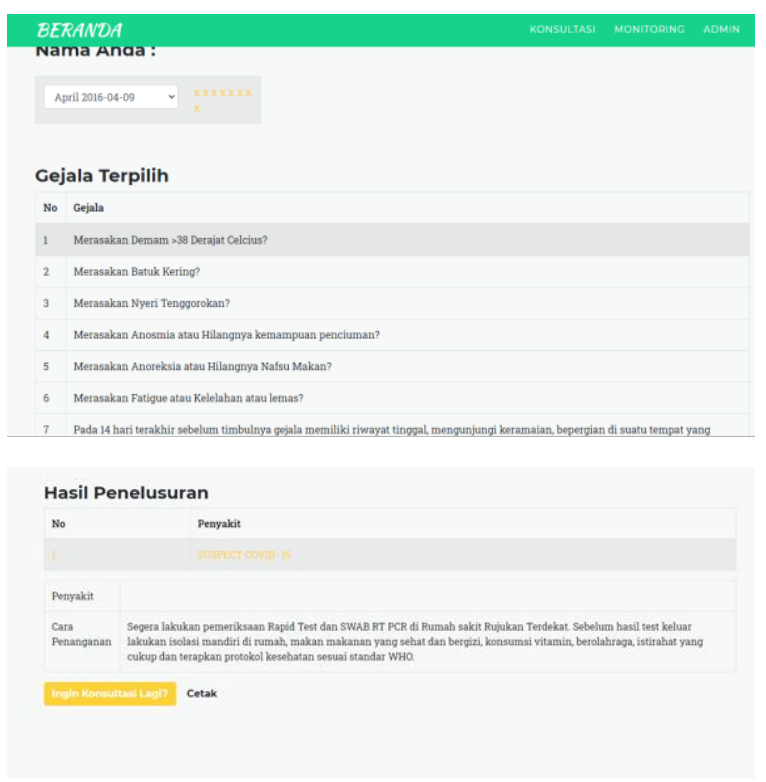

\section{Gambar 8. Hasil Screening Forward Chaining}

5. Halaman Monitoring

Halaman monitoring menampilkan penyebaran kasus COVID-19 di dunia, Indonesia maupun setiap provinsi Indonesia secara realtime.
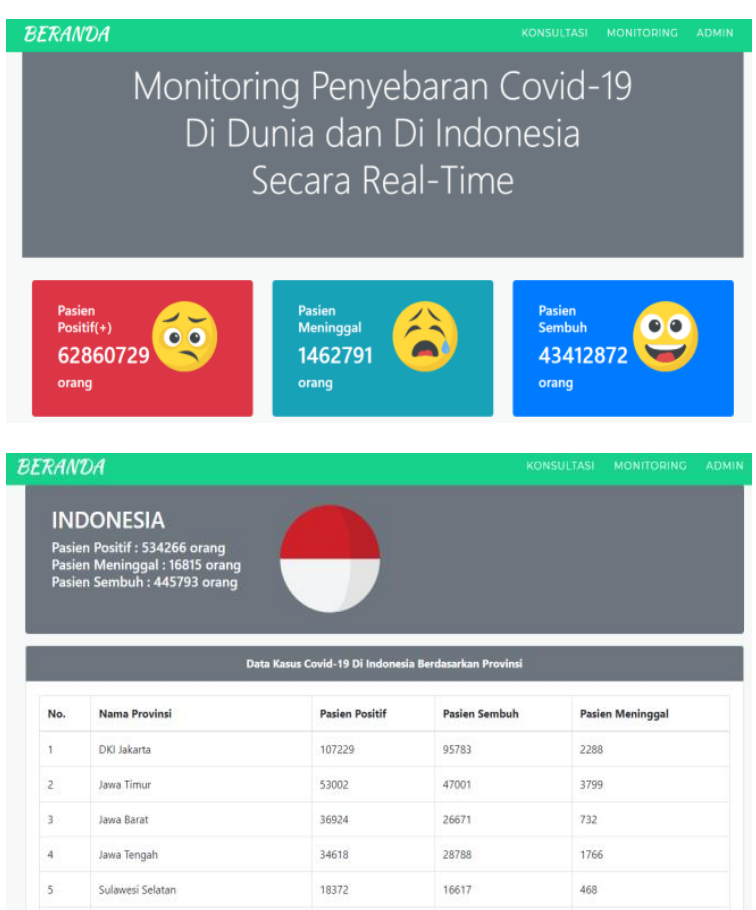

Gambar 9. Monitoring COVID-19

\section{Pengujian Sistem}

Pengujian sistem ini bertujuan untuk mengetahui tingkat ke efektifitas dan memastikan semua elemen sistem dapat berjalan dengan baik. Dalam penelitian ini menggunakan black-box testing merupakan sebuah metode untuk melihat fungsionalitas aplikasi saat dioperasikan, mengecek input diterima benar atau tidak dan output yang dihasilkan sesuai dengan harapan.

Tabel 8. Black-box Testing

\begin{tabular}{cclc}
\hline No. & \multicolumn{1}{c}{ Kelas Uji } & \multicolumn{1}{c}{$\begin{array}{c}\text { Hasil Yang } \\
\text { Diharapkan }\end{array}$} & Hasil \\
\hline 1. & Mengisi Form Login & $\begin{array}{l}\text { Masuk Kehalaman } \\
\text { Utama }\end{array}$ & Sesuai \\
2. & Mengisi Form Gejala & $\begin{array}{l}\text { Muncul Form Gejala } \\
\text { dan Dapat Dipilih } \\
\text { User }\end{array}$ & Sesuai \\
& Klik Hasil Konsultasi & $\begin{array}{l}\text { Muncul Form Hasil } \\
\text { Diagnosa }\end{array}$ & Sesuai \\
3. & Kuncul Form & Sesuai \\
4. & Klik Menu & $\begin{array}{l}\text { Monitoring Kasus } \\
\text { COVID-19 }\end{array}$ & \\
& Monitoring & $\begin{array}{l}\text { Kembali Kemenu } \\
\text { Login }\end{array}$ & Sesuai \\
5. & Klik Menu Logout & & \\
\hline
\end{tabular}




\section{SIMPULAN}

Terdapat hasil dari penelitian perbandingan dari certainty factor dengan forward chaining pada aplikasi screening dan monitoring COVID-19 sebagai berikut:

a. Dalam pengujian sistem yang dapat dilihat gambar 7 dan 8. Kedua metode ini yaitu certainty factor dan forward chaining menghasilkan diagnosis sistem dengan hasil yang sama yaitu seseorang terindikasi sebagai SUSPECT COVID-19. Namun yang membedakan pada certainty factor menampilkan hasil presentase tingkat keyakinan sebesar $98 \%$ sedangkan forward chaining tidak terdapat hasil presentase nya.

b. Dalam mendiagnosa kasus COVID19, metode certainty factor dapat dikatakan lebih akurat dalam mendiagnosa dibandingkan forward chaining karena certainty factor memiliki tolak ukur berdasarkan nilai CF pakar pada setiap gejala. Sedangkan tolak ukur pada forward chaining hanya berdasarkan rule atau aturan yang telah ditetapkan pakar tanpa ada nilai kepastiannya..

c. Halaman monitoring kasus COVID19 sangat berguna bagi user untuk memudahkan pemantauan penyebaran kasus COVID-19 di dunia, di Indoneisa maupun di setiap provinsi secara realtime.

\section{DAFTAR PUSTAKA}

[1] Fathiyah Isbaniah and Agus Dwi Susanto, "Pneumonia Corona Virus Infection Disease-19 (COVID-19)," J. Indones. Med. Assoc., vol. 70, no. 4, pp. 87-94, 2020, doi: 10.47830/jinma-vol.70.4-2020-235.
[2] A. P. Setiadi, Y. I. Wibowo, S. V. Halim, C. Brata, B. Presley, and E. Setiawan, "Tata Laksana Terapi Pasien dengan COVID-19: Sebuah Kajian Naratif," Indones. J. Clin. Pharm., vol. 9, no. 1, p. 70, 2020, doi: 10.15416/ijcp.2020.9.1.70.

[3] M. P. Sari and Realize, "Sistem Pakar Mendiagnosa Penyakit Osteoporosis pada Lansia Menggunakan Metode Forward Chaining Berbasis Web," $J$. Ilm. Inform., vol. 7, no. 01, pp. 2430, 2019.

[4] H. Fahmi, "Sistem Pakar Mendiagnosa Penyakit Mata KatarakDengan Metode Certainty Factor Berbasis Web," Matics, vol. 11, no. 1, p. 27, 2019, doi: 10.18860/mat.v11i1.7673.

[5] H. Susilo, "Sistem Pakar Metode Forward Chaining Dan Certainty Factor Untuk Mengidentifikasi Penyakit Pertusis Pada Anak," Rang Tek. J., vol. 1, no. 2, pp. 185-194, 2018, doi: 10.31869/rtj.v1i2.764.

[6] F. Al Isfahani, F. Nugraha, R. Mubarok, A. Rahmatulloh, and S. Artikel, "Informasi Artikel a B S T R a Ct," vol. 2, no. 1, pp. 33-39, 2019.

[7] E. Burhan et al., "Protokol Tatalaksana Covid-19 Tim Penyusun Perhimpunan Dokter Paru Indonesia (PDPI) Perhimpunan Dokter Spesialis Kardiovaskular Indonesia (PERKI) Perhimpunan Dokter Spesialis Penyakit Dalam Indonesia (PAPDI) Perhimpunan Dokter Anestesiologi dan Terapi Int," Klikpdpi.Com, 2020, [Online].

[8] N. Lam, S. N. Muravez, and R. W. Boyce, A comparison of the Indian Health Service counseling technique with traditional, lecture-style counseling, vol. 55, no. 5. 2015. 